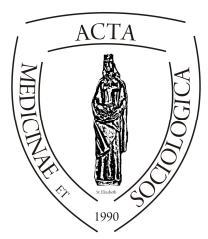

\title{
Az oktatásban dolgozó segítő szakemberek szerepe a biztonságos internethasználat kialakításában ${ }^{1}$
}

\author{
Bene Viktória \\ Szociálpolitikus, tréner, esélyegyenlőségi referens. Debreceni Egyetem Humán Tudományok Doktori Iskola \\ Szociológia és Társadalompolitika Doktori Program, 4032 Debrecen, Egyetem tér 1.
}

\begin{tabular}{|c|c|}
\hline INFO & ABSTRACT \\
\hline $\begin{array}{l}\text { Viktória Bene } \\
\text { bene.viktoria@arts.unideb.hu }\end{array}$ & \multirow{2}{*}{$\begin{array}{l}\text { The role of educational helpers in the development of } \\
\text { secure Internet use. During the development of mass } \\
\text { communication new media has appeared (for example com- } \\
\text { puter, mobile phone, laptop, tablet etc), which allow users not } \\
\text { to just be passive recipients but create and share their own } \\
\text { contents in the digital space. This has resulted countless } \\
\text { opportunities but also dangers. One of the largest dangers is } \\
\text { cyberbullying. As a result, internet safety education became } \\
\text { more and more important. In my study I give an overview } \\
\text { about the roles of helping experts in the intervention and } \\
\text { prevention of cyberbullying. }\end{array}$} \\
\hline $\begin{array}{l}\text { Keywords } \\
\text { internet safety, } \\
\text { education, } \\
\text { prevention, } \\
\text { pedagogy, } \\
\text { school social work }\end{array}$ & \\
\hline $\begin{array}{l}\text { Kulcsszavak } \\
\text { internetbiztonság, } \\
\text { oktatás-nevelés, } \\
\text { prevenció, } \\
\text { pedagógia, } \\
\text { iskolai szociális munka }\end{array}$ & $\begin{array}{l}\text { Absztrakt: A tömegkommunikáció fejlödése során megje- } \\
\text { lentek olyan új médiumok (pl. számítógép, mobiltelefon, lap- } \\
\text { top, tablet stb.), amelyek lehetővé teszik, hogy a felhasználó } \\
\text { ne csak passzív befogadója legyen a médiaüzeneteknek, ha- } \\
\text { nem belépve az interaktív térbe önmaga is hozhasson létre tar- } \\
\text { talmakat és ezeket megoszthassa másokkal a világhálón. Ez } \\
\text { számtalan lehetőséget eredményezett az emberek életében, } \\
\text { ugyanakkor a kontrollálatlan internetes tartalmak veszélyeket } \\
\text { is rejtenek magukban. Az egyik legnagyobb veszélyt az elekt- } \\
\text { ronikus zaklatás - vagy másnéven cyberbullying - jelenti. En- } \\
\text { nek következtében egyre inkább előtérbe került az internet- } \\
\text { biztonság oktatásának a kérdésköre. Tanulmányomban arra a } \\
\text { kérdésre keresem a választ, hogy a különféle segítőfoglalko- } \\
\text { zású szakemberek miket tehetnek az internetbiztonság előre- } \\
\text { mozdításában, milyen szerepük lehet a cyberbullying jelensé- } \\
\text { gének kezelésében. }\end{array}$ \\
\hline
\end{tabular}

\footnotetext{
${ }^{1}$ A tanulmány megjelenését az EFOP3.6.3-VEKOP-16-2017-00007- „Tehetségből fiatal kutató” - A kutatói életpályát támogató tevékenységek a felsőoktatásban pályázatból biztosított forrás tette lehetővé.
} 


\section{Fiatalok az IKT-térben}

Az idősebb generáció mindig másnak látja az utána következőt. Egyre nehezebb áthidalni a nemzedékek közötti különbségeket, és ezek konfliktusforrássá válhatnak. Az elmúlt tíz-húsz évben szinte követhetetlenül halmozódtak a társadalmi és gazdasági változások, továbbá a web 2.0-s alkalmazások térhódításával, az internet elterjedésével beköszöntött egyfajta információs robbanás, amelyek hatással vannak a felnövekvő nemzedékre is (Tóth-Mózer 2013).

Az EU Kids jelentéséböl kiderült, hogy a magyar gyerekek 9 évesen kezdik el önállóan használni az internetet. Azt feltételezik, hogy ez az életkor várhatóan 5-6 évre fog csökkenni a jövőben. A 9-16 éves gyerekek leggyakoribb online tevékenységei közé tartozik a videónézés, az internet használata iskolai feladatokhoz és a közösségi portálok látogatása (EU Kids Online jelentése 2011).

Kijelenthetjük, hogy a társadalmat alapjaiban változtatta meg az elmúlt évek digitális forradalma. Az egyik ilyen változás 2004 és 2008 között következett be, ugyanis ekkor vált általánossá az otthoni internethasználat, pár évvel később pedig, a 20122016 közötti időszakban széles körben elterjedtek az okostelefonok (Magyar Ifjúság Kutatás 2016). Ma már a középiskolások médiahasználatában három IKT-eszköz dominanciája figyelhető meg: ezek a telefon, a számítógép és a televízió (Guld - Maksa 2013). Ebből is láthatjuk, hogy az internet megelőzve a televíziót az elsőszámú médiummá lépett elő (Magyar Ifjúság 2016). Az internethasználatról elmondhatjuk, hogy a fiatalok körében magas az arány, míg az idősebbek esetében alacsony. Ez az arány megegyezik az uniós átlaggal, egyedül az 55-74 évesek korcsoportjában van jelentősebb elmaradásunk (Központi Statisztikai Hivatal jelentés 2015). Dr. Törőcsik Mária és munkatársai alapján tudjuk, hogy a mai fiatalok életében a televízió többnyire háttér médiahasználathoz társítható médium, ami annyit jelent, hogy csak kivételes esetekben képes az osztatlan figyelem megragadására (Guld és Maksa 2013). 2008-ig az internetezés kizárólagos színtere a számítógép volt. Viszont 2016-ra az internethozzáférés meghaladja a számítógép elterjedtségét (laptop, tablet). A fiatalok tulajdonában lévő IKT-eszközök elterjedtsége látványosan növekedett. 2012-ben csupán minden második mobilhoz tartozott internetelőfizetés. A legfrissebb statisztikák szerint viszont ma már az eszközök 70\%-a rendelkezik internettel. A 15-29 éves korosztály $88 \%$-a napi internethasználónak tekinthetö, míg negyedük folyamatosan online van. Továbbá 79\%-uk tagja valamilyen internetes közösségi oldalnak, amely 2016-ban leginkább a Facebook-ot jelentette (Magyar Ifjúság 2016).

Ahogy a fentiekben is említettük, az életünket nagyban megváltoztatta az internet megjelenése. Az információs technológia robbanásszerüen megváltoztatta azt, ahogyan egymással kommunikálunk (sz.n. Advantages and Disadvantages of ICT in the Social World. 2017). Ezekhez az eszközökhöz való hozzáférés könnyebb elérhetősége lehetővé tette a használat mértékének a növekedését. Egyre hangsúlyosabban a figyelem középpontjába került a felhasználókra gyakorolt negatív és pozitív hatás (Domonkos 2011).

A mai gyerekek számára az internet nemcsak tömegkommunikáció, hanem a személyes kommunikáció eszköze, az önmegvalósítás terepe, megnyilvánulási lehetőség. 
Az internet a személyes kommunikációnak, a másokkal való ismerkedésnek, kapcsolattartásnak új formáit teszi lehetővé. Az itt folyó kommunikáció többnyire írott, de szabályai és formája nem ritkán a szóbeli kommunikációra hasonlít. Ehhez új kommunikációs technológiákat kell elsajátítanunk, illetve ismernünk kell a médium kínálta lehetőségeket. Végül, de nem utolsó sorban tisztában kell lenni az etikett online megfelelöjével, a netikettel (Ujhelyi 2015).

\section{Cyberbullying, avagy egy új zaklatási forma meg- jelenése}

Az infokommunikációs technológia pozitívumai közé sorolhatjuk a szociális kapcsolatrendszert, a tartalomlétrehozást, a kreativitást és a technikai készségeket, a költséghatékonyságot, az oktatási lehetőségeket, a kulturális szakadék áthidalását stb, míg a negatív dolgokhoz sorolhatjuk az ártalmas tartalmakat, a rasszizmust, az agressziót, a téves információkat és a cyberbullying - ot (Domonkos 2011; sz.n. Advantages and Disadvantages of ICT in the Social World. 2017). A következőkben a témához kapcsolódóan az elektronikus zaklatás kérdéskörét fogjuk körbejárni.

A zaklatás természete az elmúlt néhány évben drámaian megváltozott. Míg korábban a zaklatás az iskolában vagy az iskola közelében történt, addig a technológia megjelenése révén már cyberbullyingról, azaz internetes zaklatásról is beszélhetünk (Patchin és Hinduja 2011). Buda Mariann (2015) Iskolai zaklatás címü könyvében olvashatjuk azt a megállapítást, miszerint Magyarország a zaklatás-kérdés kutatásának csak az első szakaszában tart (Buda 2015). A hagyományos zaklatás vizsgálata a '70-es évekre nyúlik vissza, míg a cyberbullying csak a 2000-es években került az érdeklődés fókuszába (Beran és Li 2005 idézi Zsila, Ujhelyi és Demetrovics 2015).

Kortárszaklatásról beszélhetünk olyan kortárscsoportban megvalósuló cselekmények esetén, amikor jelen van a tudatos, bántó szándék, hatalmi egyensúlyhiány áll fenn és az áldozat ellen irányuló cselekvések hosszabb ideig, ismétlődően zajlanak (Buda 2008). A bullying jelensége manifesztálódik az online környezetben: az internet a szociális kapcsolatok és a találkozások új terepe lett. Ez a fajta színtér lehetőséget ad a fiataloknak arra, hogy az anonimitást fenntartva mondjanak és csináljanak dolgokat, illetve csökkentsék a lebukás kockázatát (Ang és Goh 2010 idézi Balas-Timar et al 2017).

A cyberbullyingot úgy definiálhatjuk, mint egy szándékos és ismétlődő károkozást a számítógépek, mobilok és az elektronikus eszközök igénybevételén keresztül (Hinduja és Patchin 2009 idézi Patchin és Hinduja 2011). Megfigyelhetjük, hogy a cyberbullying és a hagyományos zaklatás definíciójában fellelhetőek a közös vonások, ugyanakkor az elektronikus zaklatás az offline, azaz nem elektronikus zaklatáshoz képest számos eltérést is mutat a fiatalok közti kommunikáció és az interakció változó természete miatt (Patchin és Hinduja 2011). Poore (2015) a következőképpen definiálja az elektronikus zaklatást: ,, bármilyen másik ember ellen irányuló, digitális technológiai eszközzel elkövetett ellenséges cselekvés” (Poore 2015:233). A szerző kerüli a „,nemzetközi” és a „szándékos” kifejezés használatát, amelyek gyakran szerepelnek az online zaklatás definíciói között. Ezt azzal magyarázza, hogy egy bizo- 
nyos kor alatt a fiataloknak nincs meg az a fajta kognitív fejlettségük, ami által tudatosan különbséget tegyenek jó és rossz között. Továbbá a definíciójában nem szerepel az ,ismételt” és „folyamatos” szó sem (Poore 2015). A definíciók többsége rámutat, hogy a zaklató magatartás ismétlődik, egyetlen kellemetlen üzenet/poszt/komment újra és újra továbbítható, széles körben terjeszthető (Boyd 2011 idézi Poore 2015). Ezt ismételt előfordulásnak is tekinthetjük, viszont az eredeti vétség egyetlen esemény volt, amely vírussá vált (Poore 2015).

A kutatók szerint az elektronikus zaklatás legveszélyesebb jellemzője, hogy szinte végtelen számú és azonnali a terjesztés lehetősége, ami miatt az áldozat még megalázottabbnak érezheti magát. Az elektronikus zaklatás másik nagy jellegzetessége, hogy az áldozat a nap bármely szakában elérhető, így az áldozat nem menekülhet el a zaklató elöl, illetve emiatt ez érzelmileg is sokkal megterhelőbb. A nemzetközi szakirodalmakból kiderül, hogy az iskolai eszközök ilyen típusú betiltása nem oldja meg a problémát (Domonkos 2013).

Az elektronikus zaklatás jellemzői közé a következő elemek tartoznak (Domonkos 2011):

- elektronikus eszköz használata

- azonnali és szinte végtelen számú terjesztés

- hozzáférhetőség

- anonimitás

- felelősségre vonhatatlanság látszata

- metakommunikációs jelek hiánya

A cyberbullying számos válfaját különböztethetjük meg. Ez jelenthet híresztelést, fenyegetést, szexuális tartalmú megjegyzést, az áldozat külső megjelenésére vagy személyes információkra vonatkozó kommenteket, üzeneteket, képeket vagy videókat. Ezek az áldozat számára komoly érzelmi és szociális következményeket vonhat maguk után vagy az áldozatot is károsíthatja, azaz öngyilkosságot is megkísérelhet (Lile 2017 idézi Balas-Timar et al 2017).

A cyberbullying vagy elektronikus zaklatás típusai a következők lehetnek: A cyberbullying első típusa a flaming vagy más néven a lángháború. Ez online veszekedést jelent dühös és trágár nyelvezet használatával. Ilyen például, ha a zaklató támadó jellegü hozzászólásokat küld valakiről nyilvános fórumra. A második típusba a harrasment vagy más néven a támadás - sorozat tartozik. Ebben az esetben bántó, igaztalan üzeneteket küld a zaklató az áldozatnak online. A harmadik típus a denigration vagy más néven a befeketítés. Ez azt jelenti, hogy kegyetlen és igaztalan pletykákat terjesztenek az áldozat hírnevének rontása céljából. A negyedik típusa az elektronikus zaklatásnak az exclusion vagy magyarul a kiközösítés. Ilyenkor kirekesztik a csoportból az online közösség egy tagját. Az ötödik típusa az impersonation, azaz a személyiséglopás. Az elkövető ebben az esetben egy idegen személy online profiljában jelenik meg, amikor a hírnevének a rontására alkalmas üzeneteket küld az idegen személy nevében. A hatodik típusba az outing, azaz a kibeszélés tartozik. Az elkövető ebben az esetben titkokat, bizalmas információkat oszt meg az áldozatról. A hetedik típus a trickery, amelybecsapást, trükközést jelent, amely során a zaklató valamilyen trükkel valakitől személyes adatok csal ki, majd ezen információkat közzé is teszi az interneten az elkövetö. A nyolcadik típus a cyberstalking, azaz az online 
zaklatás. Ezek olyan közvetlen, nyugtalanító fenyegetések, kijelentések, amelyekből látszik, hogy a szerző érzelmileg felkavart és fontolgatja, hogy magát vagy valamilyen ismerösét bántja, illetve öngyilkosságot követ el. Végül az utolsó, kilencedik típusba tartozik a sexting vagy más néven a szexting. A kifejezés a sex és a text szavak öszszevonásából jött létre. Ilyenkor az elkövető szexuálisan provokatív vagy nyíltan szexuális tartalmú üzeneteket küld el online valakinek. Ez kapja a legnagyobb figyelmet, ugyanis a meztelen képek széleskörü terjesztése valószínübb, és a fiatalokat sokkal nagyobb kockázatnak teszi ki (sz.n. Mit is jelent a cyberbullying? é.n. idézi Bene és Fegyverneki 2017) .

Az elektronikus zaklatás komoly és állandó problémának számít a fiatalok körében, amely tartós kárt okozhat és öngyilkossághoz is vezethet. Kimutatták, hogy a tizenévesek több mint felét zaklatták online és aktív félként is körülbelül ugyanenynyien vettek részt a zaklatásban. A tinédzserek több mint 25\%-át zaklatták mobiltelefonon vagy interneten keresztül. Továbbá a fiatalok több mint fele nem mondja el, hogyha zaklatják öket az interneten (i-Safe inc idézi Keen és Georgescu 2015.). A Microsoft a kutatásukban rávilágított arra, hogy a megkérdezettek 65\%-át zaklatták már legalább egyszer online. A legdominánsabb ezek közül a kéretlen kapcsolatok, fenyegetések, a sexting, illetve a harrasment (támadássorozat). Tízből nyolc embernél a családtagok, barátok érintettek voltak. A megkérdezettek 51\%-a ismerte az elkövetőt (a fiataloknál ez az arány 58\% volt) (Microsoft 2017).

A zaklatást társas folyamatként értelmezzük, amelyben a résztvevőket különböző szerepek szerint csoportosíthatjuk. A szerepekkel kapcsolatos legátfogóbb meghatározást Salmivalli és munkatársai végezték el. Összesen hat szerepet azonosítottak be, amelyek a következők: a zaklatók, az áldozatok, a segítők, a megerősítők, a védelmezők és a kivülállók (Salmivalli et al 1966 idézi Körmendi és Szklenárik 2012). A zaklató és az áldozat egy egyértelmü kategóriaként jelenik meg az eredeti tanulmányban (Körmendi és Szklenárik 2012), ugyanis külön magyarázatot nem kapcsolnak hozzá. A következőkben bemutatom a szerepek eredeti meghatározását, majd szerepeket adaptálom az online térre vonatkozatva:

Habár a zaklató és az áldozat nincs definiálva, fontosnak tartom, hogyha minimálisan is, de bemutassuk, hogy a zaklató és az áldozat az online térben hogyan jelenhet meg:

- Zaklató: Az online térben a zaklató az, aki létrehozza például az áldozat lejáratására, megalázására szolgáló oldalt, posztot vagy privát üzenetet. (Mobiltelefon esetén sms-t.)

- Aldozat: A sérelmet szenvedő fél.

- Elkövetö/áldozat: A cyberbullying szakirodalma alapján az elkövető, az áldozat és a szemlélők csoportja mellett beszélhetünk elkövetö/áldozatokról is (Ybarra és Mitchell 2004, Cao és Lin 2015 idézi Zsila, Ujhelyi és Demetrovics 2015). Az elkövetö/áldozat mind a két szerepben szerzett már tapasztalatot. A zaklatást átélt személyek gyakran maguk is ezt a viselkedésformát választják konfliktusaik, sérelmeik megoldására (Beran és Li 2007 idézi Zsila, Ujhelyi és Demetrovics 2015). 


\section{A szemlélődők (Salmivalli et al 1966 idézi Körmendi - Szklenárik 2012) csoport- jai:}

- Segítők: Az eredeti meghatározás szerint a segítők, akik aktívan segítséget nyújtanak a zaklatónak az áldozat bántalmazása közben, például lefogják az áldozatot vagy nem hagyják elmenekülni (Salmivalli és munkatársai 1966 idézi Körmendi és Szklenárik 2012). Ez a kategória nemcsak az offline zaklatásban létezik, hanem az online zaklatásban is ugyanúgy megtalálható, csak nem lefogják az áldozatot, hanem bekapcsolódnak az áldozat online megalázásába, bántalmazásába. Ilyenek lehetnek például a zaklatót bátorító kommentek vagy az áldozatra vonatkozó pejoratív kommentek.

- Megerősítők: Ők azok, akik tettekkel nem segítik a zaklatót, azaz fizikailag nem vesznek részt a zaklatásban, viszont helyeslő megjegyzéseikkel támogatják őt (Salmivalli et al 1966 idézi Körmendi és Szklenárik 2012). Az online tér különféle funkcióit figyelembe véve ide tartoznak a lájkolások és a megosztások, ugyanis olyan mértékben nem kapcsolódnak be az online bántalmazásba (nem írnak pejoratív vagy bátorító kommenteket, mint a segítők) viszont a lájkolással vagy esetleges megosztással támogatják a zaklatót.

- Védelmezők: Ök azok, akik aktívan az áldozat védelmére kelnek (Salmivalli és munkatársai 1966 idézi Körmendi és Szklenárik 2012). Ez az online térben is megtalálható. Itt gondolhatunk azokra az online térben, akik kommenteléssel kiállnak a zaklató ellen vagy jelentik az adott oldalt vagy posztot.

- Kívïlállók: Azok, akik semmilyen formában nem foglalkoznak a zaklatással (Salmivalli és munkatársai 1966 idézi Körmendi és Szklenárik 2012). Úgy gondolom, hogy az eredeti definíció az online térben is helytálló.

Zsila Ágnes és munkatársai (2015) a szemlélők csoportján belül az aktív és a passzív szemlélőket különböztetik meg (Pozzoli és Gini 2010 idézi Zsila, Ujhelyi és Demetrovics 2015). A passzív szemlélők ignorlják az agressziót vagy szótlanul figyelemmel kísérik (Obermann 2011 idézi Zsila, Ujhelyi és Demetrovics 2015), míg az aktív szemlélők reakciói lehetnek proszociálisak vagy antiszociálisak (Salmivalli és Peets 2009 idézi Zsila, Ujhelyi és Demetrovics 2015).

Meglátásom szerint az elektronikus zaklatás szerepfelosztása azon is múlik, hogy milyen környezetben megy végbe a zaklatás:

- Nyilvános: A nyilvánosság leginkább az interneten megy végbe pl. posztok és oldalak létrehozásában, támadó kommentek formájában.

- Zárt: A zaklató nem nyilvános formában zaklatja az áldozatot, hanem privátüzenetek formájában zajlik (pl. sms, e-mail, privát FB üzenet stb.) 


\section{Az oktatás szerepe az internetbiztonság elősegítésében}

A mai diákok merőben másak, mint a korábbiak voltak. Elmondható, hogy a jelenlegi oktatási rendszer nem a mai diákokra van szabva. (Prensky 2001). Számtalan iskolában egy ember foglalkozik az internetbiztonság kérdéskörével, holott az egész iskolai közösséget érinti a jelenség és ez a feladat az egész iskolára ki kellene terjedjen (European Schoolnet Academy 2017). Napjainkban digitális idegenvezetőként, minden pedagógusnak fel kell hívnia a gyerekek figyelmét a biztonságos internethasználatra (Fegyverneki 2017a).

Ideális esetben az internetbiztonság témaköre kiemelt helyet kap a következö pontokban: tanmenetbe való beépítés a releváns tantárgyaknál (nemcsak az informatika órában); a fiataloknál fontos a médiamüveltség kialakítása; partneri kapcsolatot kell kialakítani a szülőkkel és a diákokkal; törvényi elöírás a tantervben; legyen egy „ellenőrzési” funkció - ne hagyjuk magukra a diákokat baj esetén (European Schoolnet Academy 2017).

Jenkis et al (2009 idézi Bokor 2015) a médiaoktatás három lehetséges színterét különíti el, amelyek a következők: az iskolarendszer, az iskolán kívüli oktató-nevelő közösségek és a családtagok, szülök. Az iskola egy sereg médiaeszközt és mediatizált módszert kínál ahhoz, hogy a tantervekben rögzített, tantárgyalapú oktatás kiegészüljön a médiakészségek fejlesztésével. Ez a folyamat kétirányú: nemcsak a médiaeszközök és módszerek alkalmazásának elsajátítása történhet meg, hanem egyes tantárgyak tananyagai is könnyebben feldolgozhatóvá válnak (Bokor 2015). A pedagógusok részéről ezért 21. századi motivációra, korszerü tanulásszervezési eljárásokra, ${ }^{2}$ módszertani innovációra és digitális alapú jó gyakorlatokra van szükség (Fegyverneki 2016).

A modern tantervi szabályozással és a modern iskolával növekvő elvárásként fogalmazódik meg, hogy a tanulók a tanulmányaik alatt sajátítsák el a digitális média instrumentális, kreatív és kritikai-reflexív használatát. A hazai tantervi szabályozásban is egyre hangsúlyosabb szerepet kap a médiatudatosság és a digitális müveltség kérdése. 2007 óta kulcskompetenciaként van jelen a digitális kompetencia a nemzeti tantervekben, így a magyar Nemzeti Alaptantervben is (Bokor 2015).

Az iskolán kívüli médiaoktatás történhet kiegészítő módon (pl. szakkörök, tanfolyamok, klubok formájában stb.), másrészt az iskolától teljesen független formában pl. civil szervezetek keretében. Ezek azoknak az iskolásoknak nyújthatnak segítséget, akik a formális oktatás keretében egyáltalán nem kapnak médiaoktatást vagy kapnak,

\footnotetext{
${ }^{2}$ Ennél a résznél érdemes megemlítenünk a digitáliskultúra-azonos pedagógia fogalmát. A kultúra azonos pedagógia olyan konstruktivista szemléletű pedagógia, amely nagybanépít a diákok iskolán kívüli, informális szokásaira, előzetes tudására. Ez az irányzat az otthonosságot jelöli a hatékony oktatás zálogaként. A kultúra azonos pedagógia és a digitális kultúra összeolvasásából rajzolódik ki a digitáliskultúra-azonos pedagógia (digitálisan alkalmazkodó adaptív pedagógia). A digitálisan alkalmazkodó adaptív pedagógia irányzata számol azzal, hogy a diákok tanulási szokásai megváltoztak, illetve képes digitális írástudással gazdagítani a tanulók kompetenciáit (Fegyverneki 2016).
} 
de további ismeretekre vágynak. A kötetlen forma képes arra, hogy az iskolarendszerből kikerült populációt is elérje (Bokor 2015). Ennél a résznél fontosnak tartom kiemelni, hogy a számos MOOC kurzus és civil szervezet segítséget nyújt nemcsak a diákoknak, hanem tanároknak és szociális szakembereknek egyaránt annak érdekében, hogy a fiatalokat fel tudják készíteni a digitális világ kihívásaira, veszélyeire. A következőkben a teljesség igénye nélkül bemutatok pár jó gyakorlatot a témában. Nemzetközi szinten kiemelhetjük a(z) European Schoolnet Academy-t. A Brüsszelben alakult European Schoolnet 30 európai oktatási minisztérium hálózataként müködik, amely '97 óta biztosít módszertani továbbképzéseket pedagógusoknak. Később megalapították a(z) European Schoolnet Academy-t, ${ }^{3}$ hogy a továbbképzéseik több pedagógushoz eljussanak (European Schoolnet Academy honlapja). A felületen számos MOOC kurzus található, amelyek az innovatív oktatási módszerek elsajátítását segítik elő. A felületen többek között az internetbiztonság témakörében is hirdettek meg kurzust (Online Safety Course), amelynek az anyaga a honlapon elérhető. A másik MOOC kurzus, amelyet jelen tanulmányomban kiemelek, az Námesztovszki Zsolt A tudatos és biztonságos internethasználat alapjai címü kurzusa, amely a webuni ${ }^{4}$ felületén érhető el. A kurzus jó bevezető lehet azoknak a pedagógusoknak, akik szeretnének megismerkedni a témával, illetve érdeklődő diákok is részt vehetnek rajta. Az előbb említett két kurzus ingyenesen elérhető.

A Reményt a Gyermekeknek Közhasznú Egyesület és a Szubjektív Értékek Alapitvány közös projektje a „Szelíd szavakkal a gyülölet ellen - Online gyülöletbeszéd elleni nem formális nevelési program kidolgozása fiatalok és oktatási szakemberek számára". A projekt célja az online gyülöletbeszéd visszaszorítása, amely célterülete és a módszertana révén támogatja a digitális írástudás, a biztonságos internethasználat, az online etika, a tolerancia, az empátia és a szolidaritás kialakulását az ifjúsági korosztályban. A Böngésző könyvre épülö ingyenes képzésen pedagógusok, szociális szakemberek, társadalmi szervezetek képviselői és diákok egyaránt részt vehettek országszerte (Böngésző képzés honlapja). A projekt honlapján elérhető a Böngésző kiadvány, ${ }^{5}$ amely segítséget nyújthat a segítő szakembereknek az internetbiztonsággal kapcsolatos foglalkozások megtervezésére, megvalósítására.

Ahogy az előzőekben olvashattuk a médiaoktatás harmadik lehetséges színtere a család. Ezen belül is fontos szerepe van a szülöknek, akik a gyermekük első 5-6 évében nagy befolyással bírnak médiahasználati szokásaira (Bokor 2015). Megan A. Moreno könyvében felvázolja az egészséges internetezés modelljét, amelyet az Amerikai Gyermekgyógyászok Akadémiájának egyik munkacsoportjával dolgoztak ki. A munkacsoport azt javasolta, hogy hozzanak létre egy olyan modellt, amelyet az orvosok használni tudnak, amikor kamaszokkal az internetezésről beszélgetnek. A modell megalkotása során azt a célt tüzték ki maguk elé, hogy olyan eszközt adjanak a szülők és a szakemberek kezébe, amely egyszerü, átlagos és szélsőséges szituációkban is könnyen alkalmazható, továbbá különböző korú gyerekeknél és eltérő családi szituációkban egyaránt müködőképes. A modell három pillérre épül, amelyek a következők: Az első pillér az egyensúly, ami alatt azt értik, hogy a fiatal

\footnotetext{
${ }^{3}$ European Schoolnet Academy elérhetősége: http://bit.ly/2CXdysF (2018.04.11.)

${ }^{4}$ A kurzus linkje: http://bit.ly/2CRuUXw (2018.04.11.)

${ }^{5}$ Böngésző kiadvány: http://bit.ly/1YRYOfC (2018.04.11.)
} 
megőrzi az egyensúlyt az online és a valós élményei között. Azt nevezzük egészséges internetezésnek, amikor a fiatal annyi időt tölt interneten, hogy konstruktívan részt tud venni napjaink online kommunikációjában anélkül, hogy a kapcsolatai kizárólagos fórumává ez válna. Továbbá segítenünk kell, hogy a fiatalok megértsék és megtanulják, hogy az online tapasztalataik erősen befolyásolhatják a valódi életüket is. A második pillér a határok kijelölése, ami annyit jelent, hogy a gyerekeket meg kell tanítani bizonyos szabályok betartására, hogy a külvilágban - így az online média világában is - biztonságosan mozogjanak. A kérdés, hogy az online világban hol húzódnak azok a határok, amelyeket a fiatalokkal úgy jelöljünk ki, hogy azok elfogadhatóak és betarthatóak legyenek. A harmadik fontos pillért az öszinte beszélgetések jelentik, ugyanis az előző két pillér csak akkor müködhet hatékonyan, hogyha ezeket őszinte beszélgetések kísérik (Moreno 2015).

\section{Gyermekvédelem az információs társadalomban}

Az előzőekben már említetésre került a civil szervezetek fontossága mind a pedagógusok, mind pedig a diákok felkészítése szempontjából. Ebben a részben arra térek ki, hogy milyen feladat hárul az információs társadalomban az egyéb, nem pedagógus végzettségü segítőfoglalkozású szakemberekre, különös tekintettel az iskolai szociális munkás szerepére.

A zaklatás a bántalmazás egy formája, amelyre különböző emberi jogi jogszabályok vonatkozhatnak. Enyhébb esetben a magánélethez való jog merül fel és gyakran sérül is. Szélsőséges esetekben az embertelen és megalázó bánásmód tilalma vagy az élethez való jog is sérülhet (Keen és Georgescu 2016). Ennél a résznél először a Gyermekjogi Egyezmény 19. cikkének (1) bekezdését említem meg:

„Az Egyezményben részes államok megtesznek minden arra alkalmas, törvényhozási, közigazgatási, szociális és nevelési intézkedést, hogy megvédjék a gyermeket az eröszak, a támadás, a fizikai és lelki durvaság, az elhagyás vagy az elhanyagolás, a rossz bánásmód vagy a kizsákmányolás - ideértve a nemi eröszakot is bármilyen formájától mindaddig, amíg szüleinek vagy valamelyik szülöjének, illetőleg törvényes képviselöjének vagy képviselöinek, vagy bármely más olyan személynek, akinél elhelyezték, felügyelete alatt áll."

(Egyezmény a gyermekek jogairól /Elfogadta az ENSZ Közgyülése New York-ban, 1989. november 20-án. Magyarországon kihirdette az 1991. évi LXIV. törvény/)

Olvashatjuk, hogy a gyermekek alapvető jogai közé tartozik, hogy a fizikai mellett a lelki durvaságtól is óvjuk őket. Ez, ahogy az oktatásnak, úgy a gyermekvédelemnek is alapvető feladata. Ahogy a korábbiakban már részletesebben is taglaltuk, a cyberbullying vagy másnéven az elektronikus zaklatás elöl az áldozat nem menekülhet 
el, emiatt ez érzelmileg is sokkal megterhelőbb a számára (Domonkos 2013). Ezenkívül megjelenik az online zaklatás típusai között a szexuális tartalmú online zaklatás, azaz a szexting. Amikor partnerbántalmazásról beszélünk, akkor a következő típusokat különböztethetjük meg: fizikai erőszak, lelki erőszak, szóbeli erőszak, gazdasági erőszak, szexuális és reproduktív erőszak (Kuszing 2006). Ennél a résznél a lelki erőszakot emelem ki, amely adaptálható az online térre. Kuszing (2006) a lelki erőszak alábbi kategóriáit emeli ki: zsarolás, mások előtti megalázás, kedvenc tárgy, társállat megsemmisítése, gyerek megsemmisítésével, öngyilkossággal való fenyegetés, elvégzett munka állandó kritizálása, partner követése mindenhova, állandó telefonálgatás, más levelének felbontása, telefonjának lehallgatása, betegséggel való sakkban tartás (Kuszing 2006). Úgy gondolom, hogy a technika és az életritmus megváltozása folytán a szextinget is a párkapcsolati bántalmazás egyik formájának tekinthetjük. Ez a veszély nemcsak a felnőtt korosztályt, hanem ugyanúgy a fiatalkorúakat is fenyegeti.

Továbbá az 1997. évi XXXI. törvény a gyermekek védelméröl és a gyámügyi igazgatásról szóló dokumentum 6. § (5)-(6) bekezdése és az 5. § n) pontjában felmerülő gyermekjogi sérelmeket alkalmazhatjuk azokra a helyzetekre is, amikor online környezetben merülnek fel a gyermek testi, értelmi, érzelmi vagy erkölcsi fejlődését gátló vagy akadályozó körülmények (Emberi Erőforrások Minisztériuma et al 2017). A törvényben többek között megfogalmazzák, hogy a gyermekjóléti szolgáltatás a gyermek veszélyeztetettségének megelőzése érdekében iskolai szociális munkát biztosíthat (1997. évi XXXI. törvény 39. § (3a)).

Az iskolai szociális munka új típusú szolgáltatásnak számít hazánkban. Napjaink társadalmában az iskola számos társadalmi probléma forrása, amelybe többek között beletartozik a kiskorúakhoz és tanulókhoz kapcsolódó erőszak stb. A megjelenő problémák előhívják az igényt egy olyan professzionális segítő rendszeres jelenlétére az iskolákban, aki átfogó jogi, pszichológiai és szociális ismeretekkel, készségekkel rendelkezik, amelyek lehetővé teszik, hogy a gyermek fejlődését veszélyeztető problémákat korán felismerje és kezelje. Láthatjuk, hogy az iskolai szociális munkás professzió egyik lényegi elemét, a multidiszciplináris tudást feltételezik. Az iskolai szociális munkát többek között az agresszió jelensége és a mediatizált társadalom okozta problémák teszik indokolttá (sz.n. Iskolai szociális munka alapok é.n.). Magyarországon alig félszáz iskolai szociális munkás dolgozik, így a tevékenységükről viszonylag kevés tapasztalat van. 2003 és 2010 között a gimnáziumok csaknem egyharmada, az általános iskolák és szakközépiskolák egynegyede-egyötöde foglalkoztatott teljes vagy részmunkaidőben legalább egy, a gyermekjólétet segítő munkatársat. 2013-ban ez az arány jelentősen csökkent (Varga 2015 idézi Máté 2015). A kedvezőtlen változások az iskolai segítői munkával, az iskolai ifjúságvédelemmel kapcsolatban azért tűnik érthetetlennek, mert a szakértők szerint a finn tanulók PISA-felméréseken nyújtott jó teljesítményei mögött többek között az iskolai szociális munka erőfeszítései állnak (Pirkko 2013 idézi Máté 2015).

Ahogy a korábbiakban is volt róla szó, az iskolai szociális munkát többek között az iskolai agresszió jelensége és a mediatizált társadalom okozta problémák teszik indokolttá (sz.n. Iskolai szociális munka alapok é.n.), amelybe beletartozik az elektronikus zaklatás, internetbiztonság kérdésköre. A multidiszciplináris tudásnak köszönhetően, amelyet az iskolai szociális munkás birtokol, képes segítőbeszélgetés és konzultációs munka folytatására (sz.n. Iskolai szociális munka alapok é.n.), továbbá 
a közösségi technikák alkalmazására (Somogyi 2012). Az előzőekből kiindulva elmondhatjuk, hogy az iskolai szociális munkásnak széles módszertani repertoárral kell rendelkeznie a hatékony munkavégzés érdekében. Az internetbiztonság témakörénél maradva a megfelelö tudás birtokában képesnek kell lennie többek között internetbiztonsággal kapcsolatos tréningek tartására mind szülőknek, diákoknak és pedagógusoknak; projektnapok szervezésére; a megtörtént probléma kezelésére. Például a Debreceni Egyetem Egészségügyi Karán induló iskolai szociális munka szakirányú továbbképzés mintatervében szerepel az Iskolai projekttervezés tantárgy. Ez hozzásegítheti a képzésben résztvevőket különféle cyberbullying-gal kapcsolatos tematikus programok, projektnapok kidolgozására (természetesen a megfelelő tudás birtokában) egyebek melletta február 7-i Biztonságos Internet Napja alkalmára, amely felhívja az iskolában dolgozók és a tanulók figyelmét a téma fontosságára, továbbá a diákok a projektpedagógia ${ }^{6}$ módszertanának köszönhetően aktív részesei lesznek a tanulásnak.

A nevelési-oktatási intézmények müködéséről és a köznevelési intézmények névhasználatáról szóló 20/2012. (VIII. 31.) EMMI rendeletben szerepel, hogy az oktatási intézményekben a fegyelmi eljárást egy egyeztető eljárás előzheti meg. Erre akkor van lehetőség, hogyha ezzel a sérelmet elszenvedő fél, kiskorú esetén a szülő, valamint a sérelem elkövetésével gyanúsított tanuló, kiskorú esetén a szülő egyetért. Az oktatási intézmény egszükség esetén segítséget kérhet konfliktuskezelési szaktanácsadótól, valamint az ifjúságvédelmi, családjogi területen müködő szolgálattól is (20/2012. (VIII. 31.) EMMI rendelet). Ennél a résznél beszélhetünk a mediáció fontosságáról, mint alternatív vitarendezési módszerről. A módszertan alkalmazását említi a Digitális Gyermekvédelmi Stratégia is. A dokumentumban szerepel, hogy a gyermekek által vagy sérelmére elkövetett online zaklatást, megfélemlítést indokolt esetben alternatív vitarendezési mechanizmusok, resztoratív mediáció keretében kell kezelni (Digitális Gyermekvédelmi Stratégia 2017). Az iskolapszichológus szerepéről

\footnotetext{
${ }^{6}$ John Dewey, a projektpedagógia elindítója úgy vélte, hogy a tanulók jóval motiváltabbak, ha tanulás közben aktívan tevékenykedhetnek. Ez úgy lehetséges, ha a diákok valós tevékenységeken dolgoznak, miközben igazi tapasztalatokat szerezhetnek (Verók - Vincze 2011 idézi Fegyverneki 2017b). A projektpedagógia előnye, hogy a tananyag első nekifutásra gyakran nem ad elég belső motivációt a tanulóknak. Ezzel a módszerrel olyan tevékenykedtető feladatok találhatóak ki akár a diákokkal közösen a lecke feldolgozásához, amely keretében a tanulók elsajátítva a projektszemléletet tantárgyközi összefüggéseiben életszerü helyzeteknek megfelelően valós problémákon dolgozhatnak együtt. Ennek eredménye mindig valamilyen - gyakran egy nagyobb közösség érdekeit is szolgáló - produktum (projektmunka) létrehozása (Fegyverneki 2017c).

${ }^{7}$ A resztoratív, helyreállító szemlélet elsődleges célja a szabályszegés következményeként jelentkező károk feltárása és helyreállítása. A resztoratív szemlélet egyik fontos eleme, hogy a konfliktusban érintett személyek, közösségek vegyenek részt a szabályszegésre adott válaszok kidolgozásában. A mediáció egy a jövőre irányuló megoldást kereső eljárás, melynek folyamatában a közvetlenül érintett személyek vesznek részt. Az eljárás várható eredménye, hogy a konfliktus kezelése nem egy újabb konfliktus forrása lesz, hanem az érintett személyek, közösségek hosszútávon is helyreállítják kapcsolataikat (Ficsor 2011). Ez egy olyan alternatív konfliktuskezelési módszer, melynek során egy független harmadik személy, a mediátor segít a feleknek, hogy kidolgozzák a mindenki számára elfogadható megoldást (Partners Hungary Alapítvány 2017).
} 
sem szabad megfeledkeznünk, akinek ugyancsak nagy feladata lehet az internetbiztonság elősegítésében. A feladatai közé tartozik többek között az iskolában és a pedagógiai folyamatban fellelhető problémák, akadályok megértése, okok feltárása, szükség esetén a problémák korrekciója a saját eszközeivel, továbbá a prevencióban is nagy szerepet játszik. A problémafeltárást és a segítségnyújtást tanácsadói keretek közt végzi. Abban az esetben, hogyha a probléma a konzultációs kereteken túlmutat, akkor a szülőt és a diákot a megfelelő szakemberhez irányítja (Szücs 2018).

Az előző fejezetben részletezett egészséges internetezés modellje mellett érdemes megemlítenünk Parry Aftab (idézi Nagy 2010), internetbiztonságra szakosodott amerikai ügyvédnő a fiatalok számára kifejlesztett tréningprogramját, amelynek a keretében háromtípusú cselekvési módot nevez meg (hármas szabály), amelyet a fiataloknak elektronikus zaklatás esetében érdemes betartaniuk. Az első és egyben az egyik legfontosabb, hogy azonnal hagyják abba, amiket abban a pillanatban csinálnak, legyen szó bármilyen típusú online tevékenységről. Ezután használják a blokkolás funkciót a zaklatóval szemben, amely a legtöbb szolgáltatásban már megtalálható. Végül mondják el a szüleiknek a történteket (Nagy 2010). Miután megtörtént a probléma fontos, hogy a család mellette álljon az áldozatnak, mert kutatások alapján az érzelmi támogatás mérsékelte az online zaklatás negatív következményeit, és csökkentette a cyberbullying későbbi megismétlődésének valószínüségét. Ezenkívül fontos az áldozat önbizalmának a növelése, különféle megküzdési stratégiák problémafókuszú megközelítése. Továbbá fontos a tágabb környezet mozgatása, szemlélök, kortárscsoportok aktivizálása (Nixon 2014; Barlinska, Szuster és Winiewski 2013; Völlink et al. 2013 idézi Zsila, Ujhelyi és Demetrovics 2015).

\section{Összegzés}

Tanulmányomban igyekeztem bemutatni a fiatalok médiafogyasztási szokásait, jelenlétüket az IKT-térben a rájuk gyakorolt pozitív és negatív hatásokkal együtt. A tanulmány első részében megismerhettük továbbá az információs társadalom egy új jelenségét, az elektronikus zaklatást vagy másnéven a cyberbullying-ot és a segítő foglalkozású szakemberek szerepét a probléma kezelésében.

Prensky (2001) alapján kijelenthetjük, hogy a mai oktatási rendszer nem a mai gyerekekre van szabva. Ehhez kapcsolódóan bemutattam a különféle oktatási színterek szerepét a médiatudatosság kialakításában. Elmondhatjuk, hogy a digitális nemzedék megjelenésével a pedagógus szerepek is megváltoztak, alkalmazkodniuk kell az új generációhoz, azaz egyfajta digitális idegenvezetőként kell jelen lenniük a tanítási-tanulási folyamatban (Fegyverneki 2017a) és segíteniük kell diákjaiknak, hogy minél tudatosabban vegyenek részt az online világban. A szociális szakembereknek, pszichológusoknak, mediátoroknak egyaránt új szerepeket is magukra kell ölteniük a digitális robbanással párhuzamosan, ugyanis a fiatalokat ma már nem csak az iskolai zaklatás (bullying) problémája fenyegeti, hanem az online történő zaklatás, a cyberbullying, amelynek kezelésében meg kell állniuk a helyüket szükség esetén.

Mindkét segítőfoglalkozású csoportot nagy kihívás elé állította ez a jelenség és ezáltal elmondhatjuk, hogy nemcsak a diákoknak, hanem a pedagógusoknak, szociális 
szférában dolgozóknak is tudásbővítésre, továbbképzésekre van szükségük. A fentiek és a tapasztalataim alapján szemléletváltásra van szükség mind a szociális szakemberek képzésében, mind a pedagógusképzésben, ugyanis az elektronikus zaklatás témaköre nem minden esetben jelenik meg különféle tantárgyak keretében, mintatervekben. Mindenképpen pozitív, hogy ezt kompenzálva vannak olyan kezdeményezések, amelyek ezt a hiányosságot igyekeznek leküzdeni és módszertani eszközöket nyújtanak a segítőfoglalkozású szakembereknek.

\section{Felhasznált szakirodalom}

1. Balas-Timar, D., Demeter, E., Putin C., Rad, G. (2017): The dynamic relationship between consent silence and victim empathy in cyberbullying. http://bit.ly/2CUjq5H Utolsó letöltés: 2018. január 07.

2. Bene Viktória, Fegyverneki Gergő (2017): Hogyan tanítsuk tréningen és tanórán az etikus és biztonságos mobilhasználatot? In: Aknai Dóra Orsolya - Fehér Péter (szerk.), Mobil - világ - iskola. Válogatott tanulmányok az I. Mobil eszközök az oktatásban konferenciáról. Debrecen, Debreceni Egyetemi Kiadó 192-199. oldal.

3. Bokor Tamás (2015): Médiaértés. In: Aczél Petra (szerk.), Müveljük a médiát! Budapest, Wolters Kluwer Kft.

4. Böngésző képzés honlapja: http://bit.ly/2CVpOZC Utolsó letöltés: 2018.január 02.

5. Buda Mariann (2008): Iskolai erőszak, iskolai zaklatás. Fordulópont, (10)3, 11 25. oldal.

6. Buda Mariann (2015): Az iskolai zaklatás. Debrecen, Debreceni Egyetem Kiadó

7. Digitális Gyermekvédelmi Stratégia 2017.

8. Domonkos Katalin (2011): Cyberbullying - elektronikus zaklatás.: http://bit.ly/1vjSUTeUtolsó letöltés: 2014. november 20.

9. Domonkos Katalin (2013): Digitális felelősség és kötelezettség mint a digitális állampolgárság kompetenciaterülete. http://bit.ly/1BKKMzU Utolsó letöltés: 2018. január 02.

10. Egyezmény a Gyermekek Jogairól: https://bit.ly/2GZNYRz Utolsó letöltés: 2018.január 02.

11. Emberi Erőforrások Minisztériuma - Szociális Ügyekért és Társadalmi Felzárkózásért Felelős Államtitkárság - Gyermekvédelmi és Gyámügyi Főosztály (2017): A magyar gyermekvédelmi rendszer müködése az online környezetben történő gyermekveszélyeztetés tükrében.: http://bit.ly/2CIv67q Utolsó letöltés: 2018. január 07.

12. EU Kids Online II. A magyarországi kutatás eredményei. 2011 Budapest, Nemzeti Média és Hírközlési Hatóság.

13. European Schoolnet Academy (é.n.): About us. http://bit.ly/2mhO26Q Utolsó letöltés: 2018. január 07.

14. European Schoolnet Acedemy-Online Safety Course MOOC 2017. http://bit.ly/2nIgPDO Utolsó letöltés: 2018. január 07. 
15. Fegyverneki Gergő (2016): IKT-s ötlettár. Gyorstalpaló digitáliskultúra-azonos pedagógiából kezdőknek és haladóknak. Budapest, Neteducatio. Kft.

16. Fegyverneki Gergő (2017a): A kaméleon-pedagógus így csinálja... Inspiráló ötletek modern pedagógusoknak. Budapest, Neteducatio Kft.

17. Fegyverneki Gergő (2017b): Digitáliskultúra-azonos pedagógia: a motiváció és a tananyagszerkesztés új útja? Egy digitális projekt tapasztalatai In: Polonyi Tünde, Abari Kálmán (szerk.), Digitális tanulás és tanítás. Debreceni Egyetem Kiadó 121-134. oldal.

18. Fegyverneki Gergő (2017c): Digitális generációhoz igazított pedagógia - módszertani továbbképzés pedagógusok számára. Mesterkurzus. Budapest, Neteducatio. Kft. (elektronikus tananyag).

19. Ficsor Magdolna (2011): Tudunk segíteni? - Resztoratív gyakorlatok egy iskolai konfliktus tükrében. http://bit.ly/2EpQiQ6 Utolsó letöltés: 2018. január 09.

20. Guld Ádám, Maksa Gyula (2013): Fiatalok kommunikációjának és médiahasználatának vizsgálata - tanulmány. Pécs, Pécsi Tudományegyetem.

21. Keen, E., Georgescu, M. (2015, 2016): Böngésző. Emberi jogi neveléssel az online gyülöletbeszéddel szemben. Budapest, Reményt a Gyermekeknek Közhasznú Egyesület.

22. Körmendi Attila, Szklenárik Péter (2012): Az iskolai zaklatás. Debrecen, Debreceni Egyetemi Kiadó.

23. Központi Statisztikai Hivatal jelentés 2015.

24. Kuszing Gábor (2006): A partnerbántalmazás a nők elleni erőszak egy fajtája. http:bit.ly/2qH69a2 Utolsó letöltés: 2017. május 10.

25. Magyar ifjúság 2016 kutatás első eredményei. Budapest, Kutatópont Kft.

26. Máté Zsolt (2015): Az iskolai szociális munka 2015. Esély, (27)4. 77-95. oldal.

27. Microsoft (2017): Civility, Safety and Interaction Online. http://bit.ly/2CKN8WL Utolsó letöltés: 2018. január 02.

28. Moreno, M. A. (2015): Szex, drogok, Facebook. Internethasználati kalauz szülőknek. Budapest, Móra Könyvkiadó.

29. Nagy Tamás (2010): Elektronikus zaklatás - Cyberbullying. http://bit.ly/1zKT39L Utolsó letöltés: 2018. január 02.

30. Partners Hungary Alapítvány (2017): Mediáció. Az egyezségteremtés múvészete. Kézikönyv. Budapest, Partners Hungary Alapítvány

31. Patchin, J. W., Hinduja, S. (2011): Traditional and Nontraditional Bullying Among Youth: A Test of General Strain Theory. Youth \& Society, (43) 2 pp. 727-751.

32. Poore, M. (2015): Hogyan használjuk a közösségi médiát az oktatásban? Budapest, Wolters Kluwer Kft.

33. Prensky, M. (2001): Digital natives, digital immigrants. http://bit.ly/2ySL1ib Utolsó letöltés: 2018. január 07.

34. Somogyi Ildikó (2012): Az iskolai szociális munka rendszerintegrációs kérdései. Metszetek, (1)2-3. 108-114. oldal.

35. sz.n. (2017): Advantages and Disadvantages of ICT in the Social World. http://bit.ly/2D9UeVR Utolsó letöltés: 2018. január 07.

36. sz.n. (é.n.): Az iskolai szociális munka alapjai. http://bit.ly/2Er91JF Utolsó letöltés: 2018. január 07. 
37. Szücs Imre (2018): Az iskolapszichológus feladatai.: http://bit.ly/2qJY8SH Utolsó letöltés: 2018. január 07.

38. Tóth-Mózer Szilvia (2013): A gyermekkép az információs társadalom hajnalán. In: Pál Dániel Levente (szerk.), Oktatásinformatikai módszerek. Tanítás és tanulás az információs korban. Budapest, ELTE Eötvös Kiadó.

39. Ujhelyi Adrienn (2015): Az internet mint szocializációs közeg. In: Kósa Éva (szerk.), Médiaszocializáció. Budapest, Wolters Kluwer Kft.

40. Zsila Ágnes, Ujhelyi Adrienn, Demetrovics Zsolt (2015): Online zaklatás a legújabb kutatások tükrében. Imágó Budapest. (4)4 50-64. oldal.

41. 1997. évi XXXI. törvény a gyermekek védelméről és a gyámügyi igazgatásról.

42. 20/2012. (VIII. 31.) EMMI rendelet - a nevelési-oktatási intézmények múködéséről és a köznevelési intézmények névhasználatáról. 